\section{EMBRYAIDDLE \\ Aeronautical University}

SCHOLARLY COMMONS
International Journal of Aviation, Aeronautics, and Aerospace

\title{
Contingency Fuel Reduction in Brazil
}

\author{
Diogo Youssef \\ Azul Airlines, diogo.youssef@voeazul.com.br \\ Fabiano Gomes De Oliveira \\ Embry Riddle Aeronautical University, GOMESDEF@my.erau.edu \\ Joao Centeno \\ Gol Airlines, jccenteno@voegol.com.br \\ Luciano Figueiredo \\ LATAM Airlines, luciano.figueiredo@latam.com \\ Leila Halawi \\ WW/COA, halawil@erau.edu
}

Follow this and additional works at: https://commons.erau.edu/ijaaa

Part of the Air and Space Law Commons, Legislation Commons, and the Other Law Commons

\section{Scholarly Commons Citation}

Youssef, D., Gomes De Oliveira, F., Centeno, J., Figueiredo, L., \& Halawi, L. (2020). Contingency Fuel Reduction in Brazil. International Journal of Aviation, Aeronautics, and Aerospace, 7(3). https://doi.org/ 10.15394/ijaaa.2020.1500

This Article is brought to you for free and open access by the Journals at Scholarly Commons. It has been accepted for inclusion in International Journal of Aviation, Aeronautics, and Aerospace by an authorized administrator of Scholarly Commons. For more information, please contact commons@erau.edu. 
Airlines flying in Brazil have their regular operations ruled by RBAC, Regulamentos Brasileiros de Aviação Civil, the Brazilian Aviation Civil Regulation, Part 121. The requirement states that any flight must have enough fuel to go from origin to destination (point A to point B). Also, the flight must have fuel to the alternate airport (point $B$ to point $C$ ), plus a contingency fuel that equals the fuel quantity required to fly $10 \%$ of the flight time from A to B (AAC, 2019). This $10 \%$ fuel for contingency is a number defined in the past by the local authority to cover errors during performance calculations, errors in the aircraft navigation, and also due to inadequate or non-existent meteorology forecasting. The sum of these errors requires additional fuel to make in-flight corrections to unpredicted situations (Hao et al., 2016). However, the technical development in aviation brought more accuracy to the air navigation, and more reliability to the computerized flight planning performance calculations and meteorology forecasting. This evolution was possible because nowadays, the systems are integrated with other tools in the airline, increasing the database for predictions and analysis (Altus, 2009).

Today, the major commercial aircraft manufacturers equip their airplane models with navigation systems that, in conjunction with the flight plan and existing meteorology forecasting, are capable of precisely predict the atmosphere condition on every flight level and every mile of the flight. These technological enhancements of current aviation are reducing the differences between the planned and actual fuel burn. Companies intend to keep investing in flight planning systems and modern aircraft because, in this way, airlines can save fuel with accurate and optimized flight plans applied to flight operations (Altus, 2009).

\section{Problem}

According to the ANAC, Agência Nacional de Aviação Civil, the Brazilian Aviation Authority, fuel is one of the airlines' highest costs. In Brazil, fuel cost has represented $24.8 \%$ to $29.5 \%$ of airline costs composition from 2015 to 2017. As shown in Figure 1, we display the cost composition of Brazilian companies, including fuel, rental, maintenance, depreciation, and airport fees, amongst other costs (ANAC, 2018). 


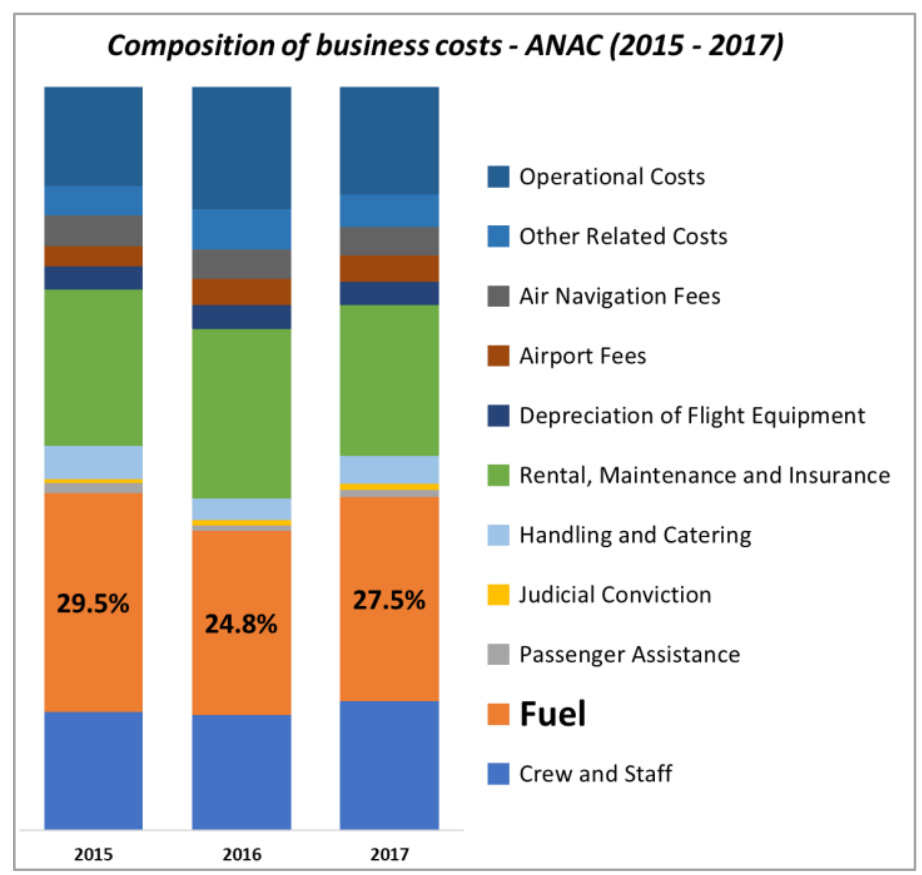

Figure 1. Composition of Business Costs - ANAC (2015 - 2017).

Due to the high impact of fuel to airlines costs composition and the continuous intention to reduce costs and also $\mathrm{CO}_{2}$ emission, almost all airlines around the world are attempting to find ways to increase fuel efficiency actions and reduce the unnecessary, or unwanted, fuel burn following ICAO recommendations (Johnson et al., 2013). It is essential to highlight that fuel burning is part of the aircraft operation. Thus, it is part of the business, and the total fuel burnt is directly related to the aircraft's weight when flying. In general terms, airlines aim to operate with the highest number of passengers and or cargo. Airlines must avoid all unnecessary non-paying loads, such as any unneeded fuel quantity, which would only increase weight but provides no revenue. This dilemma brings us to the core of this research. The fuel burned has a direct correlation with the actual aircraft weight. Therefore, more fuel carried represents more fuel consumed, and the total aircraft weight should avoid any unwanted or unnecessary weight. In other words, the goal is to reduce the Marginal Fuel Burn (MFB), a concept that states that the incremental fuel burnt to transport a particular load by a certain leg length.

MFB is historically between $2.5 \%$ and $5 \%$ of each kilogram of fuel per flight hour (Denuwelaere, 2012). Civil Aviation Authorities around the world, such as Australian, Chilean, European, and Mexican, for example, already identified that the contingency fuel required by their aviation regulation was beyond the real contingency fuel for safe operations (CASA, 2018). After comparing predicted versus actual fuel burnt, and the evaluation of the number of flights diverted due to 
fuel emergencies, those authorities have reduced the necessary contingency from $10 \%$ to lower values as $5 \%$. In some cases, those authorities permit the use of $3 \%$ (EASA, 2019). The FAA, in the United States, keeps $10 \%$ as a general requirement to all regular operators. However, the FAA allows airlines to define their contingency fuel requirements for domestic flights. Also, the FAA grants a deviation for international flights to keep a $10 \%$ value in the segment of the trip where the aircraft's position cannot be determined at least one time per hour. This is a special surveillance requirement. In other words, the FAA gives the airline the responsibility to manage its policies for the application of the contingency fuel percentages (FAA, 2015). Brazilian aviation has similarities with the cited countries when looking to the aircraft types operated; we fly state of the art airplane models from all significant airplane manufactures such as Airbus, Boeing, and Embraer. Our operational rules regarding maintenance requirements and airspace navigation, for example, are also under the same kind of scrutiny that airlines have in Europe and the USA. And finally, the software used on dispatches, and our crew training programs also follow recognizable international standards such as IOSA (IATA Operational Safety Audit). Therefore, it is reasonable to conclude that Brazilian fuel requirements can be reviewed to also be in line with the most updated rules.

\section{Purpose}

This study proposes to scientifically support a change in the Brazilian aviation regulation, RBAC 121 , to reduce the percentage of the current contingency fuel from $10 \%$ to $5 \%$ for all airlines, and to evaluate lower contingency fuel values based on specific authorization requirements. ABEAR proposed this change. ANAC reviewed this research and approved the changes in regulation in February 2020. The new law took effect on April $1^{\text {st }}, 2020$.

\section{Existing Fuel Regulations and Practices Regulatory Contingency Fuel}

The existing requirement for contingency fuel in the current RBAC 121 is based on the older versions of Brazilian aviation regulation, RBHA 121, and has inherited its rules from the beginning of the Brazilian airlines' operations. The first versions, based on the FAA regulation, defined the required contingency fuel as a number enough to compensate unforeseen factors, navigation error, or even calculations error in the dispatch process. However, aviation in the world experienced the lead technological development along the last decades, changing the precision of the estimates, bringing precise navigation to the airlines, and promoting accurate meteorology forecasts (Schneider, 2009). Other regulatory agencies around the world, such as American, Australian, Chilean, European, Mexican, etc., that also use standardized rules for determining the requirements for 
fuel planning, have stepped forward. They evolved to a more modern approach of their legislations., based their minimum requirements on the existing rules from the International Civil Organization Association (ICAO). According to Standard and Recommended Practices (SARP) 4.3.6.1 (ICAO, 2013), a flight shall not be initiated unless it takes into consideration the meteorological conditions and delays expected in the flight. The aircraft has enough fuel to accomplish the flight safely.

Additionally, a 5\% reserve fuel shall be considered for contingencies and unforeseen situations that shall not be lower than the amount required to fly for five minutes at holding speed at $450 \mathrm{~m}(1500 \mathrm{ft})$ above the destination aerodrome in standard conditions (ICAO Annex 6, chapter 4.3.6). The European Aviation Safety Agency (EASA) Regulation, in its Commission regulation 965, dictates technical requirements related to air operations that contain fuel regulations. This particular part of the European law states that the operator to the flight planning shall define a fuel policy. This ensures that every flight has enough fuel for the planned operation and enough reserve fuel to cover deviations and contingencies (EASA, 2012). Table 1 summarizes the contingency fuel requirement adopted by the authorities from relevant aviation markets.

Table 1

Percentage of Contingency Fuel per Country/Region

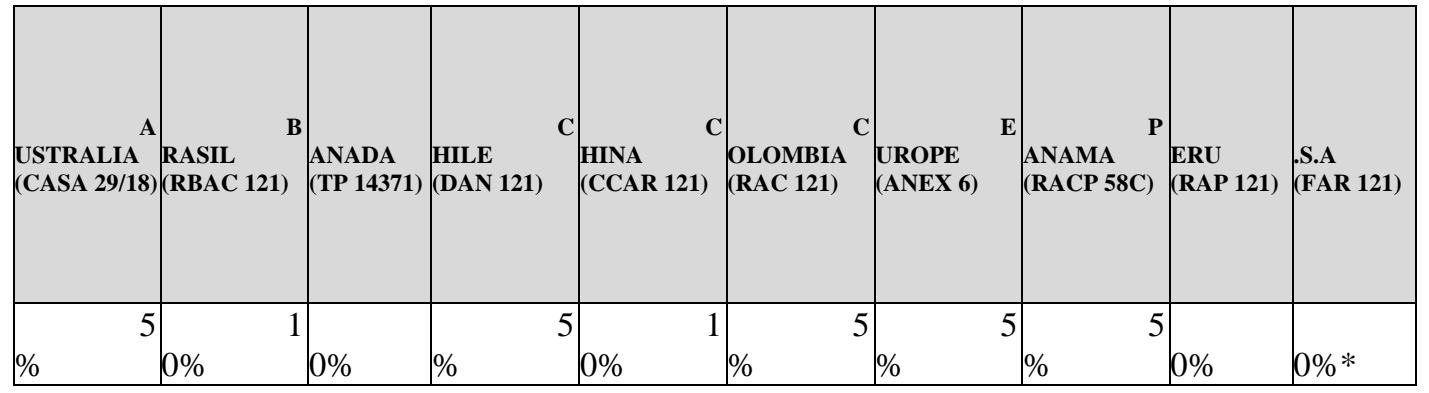

* Under particular deviations, FAA permits the dispatch of domestic flights without contingency fuel, and international flights with $10 \%$ only in segments without determined surveillance level.

\section{Fuel Planning}

In the airline environment, every flight planning has the participation of the flight dispatch department. This department has, among others, the responsibility to calculate the total fuel required to complete the planned flight. This calculation takes into account the aircraft model performance, flight route, operational limitations, loads, weather conditions, and the minimum fuel required as defined by local regulation (Dispatcher.org, 2019). The needed minimum fuel is composed 
of different parts and has a single calculation for each specific flight every day. As differences in wind, meteorology, aircraft degradation, total weight, may require more or less fuel.

The existing Brazilian regulation for airlines, RBAC 121, has in its requirements the minimum fuel planning. Paragraph 121.645 mandates that each operator must take into consideration wind and known meteorology conditions to calculate fuel for every flight of the jet plane. The computation should consider having enough fuel to fly to and land in the destination airport, fly a period equals to ten percent of the total time required from the origin to the destination airport (Contingency Fuel), fly to and land in an alternative airport, and Fly thirty minutes, on holding speed as applicable to the aircraft model, on a height of one thousand and five hundred feet from an alternative airport.

The requirements of the RBAC 121.645 are graphically demonstrated in Figure 2, which also gives an overview of the composition of the minimum fuel onboard the aircraft. Any other extra fuel defined by company policies can be added to the available volume of the tank. However, this extra fuel cannot substitute the minimum required fuel.

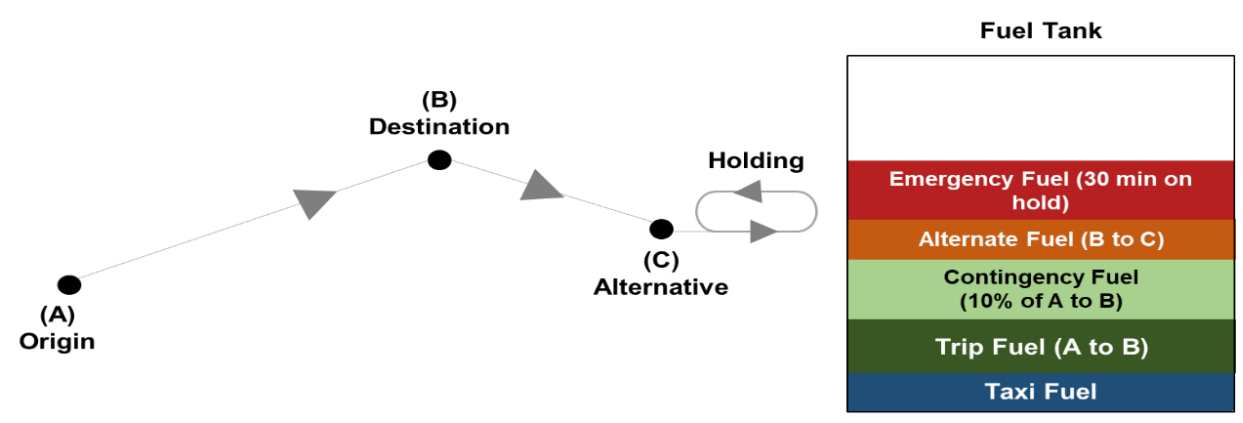

Figure 2. Composition of the Minimum Required Fuel in Brazil.

Airlines are continually looking for fuel savings by the reduction of fuel burning. One of the most used strategies is to reduce the onboard fuel to have lower final aircraft weight, thus reducing fuel consumption (Airbus, 2004). On each of the above segments of the required fuel, airlines have the means to manage and work in the reduction of fuel needed. Although they have different ways of contributing to fuel-saving, their mutual effort can bring significant fuel saving results for the Airline (Airbus, 2004). According to Boeing, companies spent 10\% more fuel than required in 2011. To increase fuel efficiency, pilots can manage some phases of flight. Examples include taxis, optimizing routes, optimum flight levels, and different regimes on trips. Also, the airlines must apply procedures as fuel conservation strategies in the takeoff, climb, cruise, descent, approach, and taxi phases (Boeing, 2010). According to Airbus, we can reduce Taxi fuel by applying a technique as the use of one engine for taxi and management of optimum moment 
to start engines (Airbus, 2004). The Trip fuel can be managed by the airlines, mainly for pilots, by the application of several actions from the takeoff to the landing. The most used techniques pass through the implementation of proper takeoff flaps policies. These policies can influence the fuel consumption directly, the definition and the use of shortest routes, and the use of optimum flight levels that can contribute to reducing the in-flight fuel burnt.

As an example of the impact of an optimum flight level policy application, flying at 2.000 below the optimum altitude can increase $2 \%$ of fuel burn (Boeing, 2010). Alternate fuel can be managed by airlines by the strategic choice of the alternative airports to be used for each route. Usually, airlines also take into account other costs arising from a diverted flight but still take into account the fuel required by regulation for this phase. Extra fuel is part of the company's policies and is covered by the strategic decisions to manage any amount of additional fuel or the need to cut it. Finally, the Final Reserve Fuel of 30 minutes cannot be reduced as it is the only supply in cases of final emergency and is mandated by ICAO Annex 6. (ANAC, 2018). We can see that airlines have the means to work and manage the fuel burnt by applying internal procedures, fuel savings techniques, and operational policies. However, airlines cannot control the $10 \%$ contingency fuel, as it is mandatory. Even when having the exact dispatch process and modern aircraft that could justify the reduction of this percentage, the airline is obligated to transport extra-weight in unnecessary contingency fuel, which increases costs.

\section{Risk Management and Assessment}

A reduction in the contingency fuel results directly in less fuel onboard and may sound like a reduction on the safety level, and consequently, higher risks to the flight operations. However, airlines have the means to manage the risk by assessing, evaluating, and controlling all phases of flight, from planning and dispatch, until monitoring on real-time all flights from takeoff to landing. The airline operations, including flight operations, have inherent risks, and risk management is the ability to achieve the business goals by integrating economic, environmental, and social opportunities with the business strategy keeping the operationally acceptable safety level (Flouris et al., 2011). Like other activities of high risk, aviation needs to have thorough and comprehensive studies for implementing new processes and procedures to evaluate implementation feasibility. One of the best ways to analyze the risks involved is through risk assessments (ICAO, 2013). Risk assessment consists of maintaining risks at some acceptable level before the implementation. The process starts with a crucial phase of hazard identification, and after analyses, risks are set in a matrix of severity, and the probability of harm or damage occurs. It is noticeable that risk assessment is vital to the risk management process and is essential in the core competency of safety professionals (ICAO, 2013). Applying the risk assessment to the reduction of contingency fuel percentage would result in apparent hazards of lack of fuel to 
the planned trip and the need to use the Final Reserve Fuel, entering in the emergency condition. Therefore, the risk assessment intends to raise this evident and severe hazard. In contrast, the risk management wants to find means to control and keep acceptable safety levels in the flight operations.

\section{Research Methodology}

This research uses two parallel methodologies to evaluate the impacts of the reduction of the regulatory contingency fuel from $10 \%$ to $5 \%$. The starting point is an analysis of the flight's historical database, provided by two of the three major Brazilian airlines. The actual contingency fuel on departure is mathematically replaced by $5 \%$ to check the remaining fuel on landing and the global impacts of this change as a qualitative analysis. The second part simulates multiple flights with different inputs of fuel planning (taxi fuel, trip fuel, additional fuel, etc.) and the $5 \%$ proposed rule, and use randomization to calculate the remaining fuel on landing for different conditions created by the model.

The Monte Carlo methodology intends to simulate random scenarios to find if any percentage of flights that consumed all its fuel after reducing the contingency requirement to 5\% (Shreǐder et al., 1966). We were able to simulate real flight conditions using the airline historical database to calculate initial fuel onboard, fuel used on each different flight, and the remaining fuel on landing. The information on the databases is a stratified sampling of the totality of the Brazilian aviation. The database represents $60 \%$ of Brazilian operations considering the number of flights and covers six to twelve months of services, and contains the relevant operational information to this research. After the data cleaning, the list remained with a total of 293,488 flights. Following the ANAC records, in the same period, both airlines together made 371,339 flights. The final spreadsheet includes the columns with the following calculated variables to support the analysis: TOTAL FUEL 10 (Total fuel on board with 10\% contingency fuel); TOTAL FUEL 5 (Total fuel on board with 5\% contingency fuel); USED TRIP FUEL - Total fuel used in the flight; LAND 5\% (Total fuel on landing if the contingency fuel was 5\%:); DIFF FOB (Difference on Fuel On Board when comparing rules of $10 \%$ and 5\% for contingency fuel); and DIFF F.BURN (Difference on fuel burn due to the DIFF FO). The target is to identify flights that would have fuel onboard under the minimum limits when being dispatched using five percent of contingency fuel in the planning phase. In other words, to evaluate when LAND 5\% is smaller than RESERVE FUEL. Then, these two additional columns are created in the spreadsheet: GROUP - Classification of the flight per its duration and CONSUMPTION FACTOR - Relation of actual and planned trip fuel. A snapshot of the spreadsheet is presented in Table 2. 
Table 2

Example of Final Spreadsheet Calculation

\begin{tabular}{|c|c|c|c|c|c|c|c|c|c|}
\hline $\begin{array}{c}\text { UNIQUE } \\
\text { ID }\end{array}$ & $\begin{array}{c}\text { TRIP FUEL } \\
\text { PLAN }\end{array}$ & $\begin{array}{c}\text { TOTAL } \\
\text { FUEL 10 }\end{array}$ & $\begin{array}{c}\text { TOTAL } \\
\text { FUEL 5 }\end{array}$ & $\begin{array}{c}\text { USED TRIP } \\
\text { FUEL }\end{array}$ & $\begin{array}{c}\text { LAND } \\
\mathbf{5 \%}\end{array}$ & $\begin{array}{c}\text { DIFF } \\
\text { F.BURN }\end{array}$ & $\begin{array}{c}\text { DIFF } \\
\text { FOB }\end{array}$ & RANGE & $\begin{array}{c}\text { CONSUMPTION } \\
\text { FACTOR }\end{array}$ \\
\hline 1 & 1896 & 6175 & 6104 & 1800 & 4304 & -96 & $-71,20$ & $\mathrm{~A}$ & $-1,40$ \\
\hline 2 & 1641 & 7171 & 7121 & 1400 & 5721 & -241 & $-49,95$ & $\mathrm{~A}$ & $-0,93$ \\
\hline 3 & 2465 & 6474 & 6409 & 2400 & 4009 & -65 & $-64,75$ & $\mathrm{~A}$ & $-1,68$ \\
\hline 4 & 2404 & 6474 & 6393 & 2300 & 4093 & -104 & $-80,80$ & $\mathrm{~A}$ & $-2,08$ \\
\hline
\end{tabular}

\section{Model Spreadsheet}

The model for simulation is written in a separate spreadsheet where the Excel application, Oracle Crystal Ball, can run separately for each group of flights. The modeling is the calculation of the random fuel quantities of each variable of the model (PLANNED TRIP FUEL, CONTINGENCY FUEL, ALTERNATE FUEL, RESERVE FUEL, TAXI FUEL, EXTRA FUEL, and CONSUMPTION FACTOR), respecting the historical behavior of each of data separately, to find the remaining fuel of each simulation.

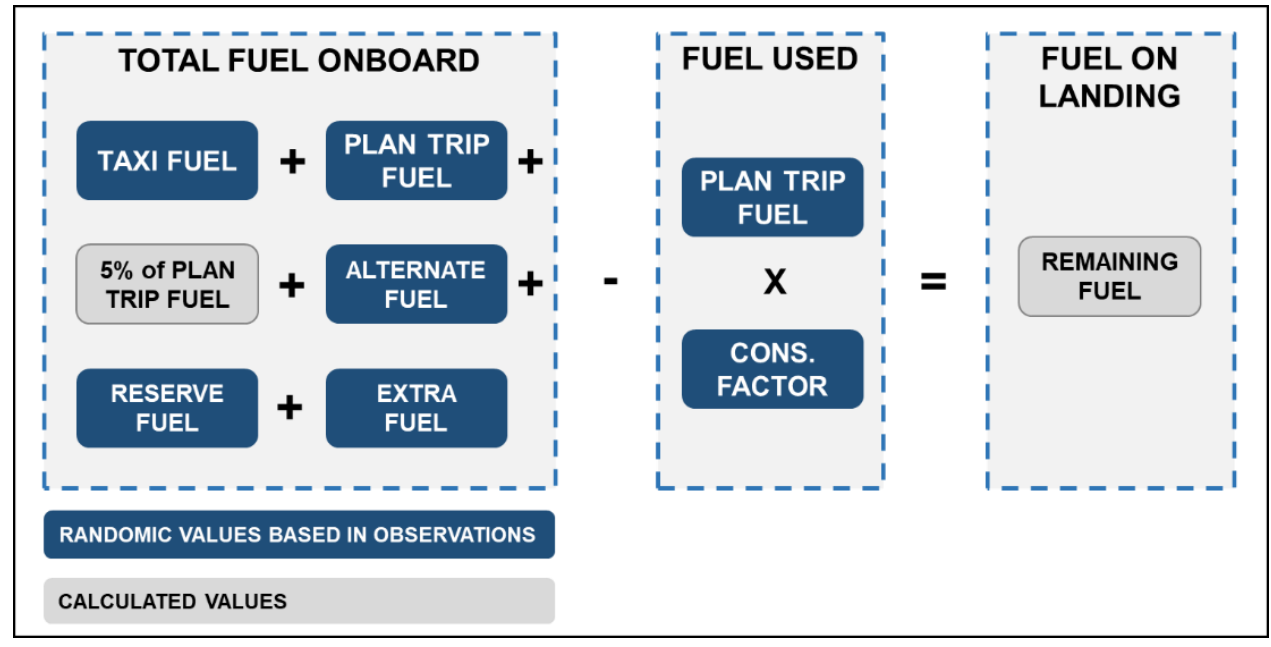

Figure 3. Simulation Model for Remaining Fuel with 5\% of Contingency Fuel.

Figure 3 above illustrates the relationship between variables in the model, the calculation to find the remaining fuel of each flight, and the variables that receive the values randomized by the Monte Carlo methodology using historical data from the Simulation Spreadsheet described in the item before. A mathematical model used this statistical information to simulate the remaining fuel on board of simulated flights, and compare with the minimum reserve fuel (holding fuel), to conclude if any flight could be severely affected by the change on the contingency fuel from $10 \%$ to $5 \%$. 


\section{Research Outcomes}

Both Airline A and Airline B provided flight planning historical data and also actual flight data received automatically via ACARS from flights in the same period. This study compared both information to find pairs of "actual vs. planned" and cleaned the data using the process mentioned in the previous section. These actions resulted in several flights enough to run analysis and predict results using actual data, with the representativeness of $99,92 \%$ of the sample, as per Yamane's sample size formula calculation. Table 3 provides details about sampling sizing and confidence interval calculation.

Table 3

Analysis of Flights Data Sampling

\begin{tabular}{cccc}
\hline AIRLINE & Airline A & Airline B & Total \\
\hline $\begin{array}{c}\text { Number of flights } \\
\text { (Sample Size) }\end{array}$ & 211,839 & 81,649 & $\mathbf{2 9 3 , 4 8 8}$ \\
\hline Period in the sampling & 12 Months & 7 Months & - \\
\hline $\begin{array}{c}\text { Total flights in the period } \\
\text { (Population) }\end{array}$ & 249,663 & 121,736 & $\mathbf{3 7 1 , 3 3 9}$ \\
\hline Sample Size \% & $84.85 \%$ & $67.07 \%$ & $\mathbf{7 9 . 0 2 \%}$ \\
\hline $\begin{array}{c}\text { Representativeness } \\
\text { (Confidence Interval) }\end{array}$ & - & - & $\mathbf{9 9 , 9 2 \%}$
\end{tabular}

However, there are several different types of flights contained in the dataset, which do not allow us to compare them directly. These flights are operated by different aircraft models, flying different distances, carrying different weights, in multiple combinations of these factors. Therefore, to better explore the data, the outcomes are presented categorized by the flight duration, which is the factor that most directly affects the amount of fuel burnt by the aircraft.

For this research, the flight durations were categorized in five different blocks, separated by one hour difference, as follows:

- Group A - Flights with a duration of 1 hour or less

- Group B - Flights with a duration above 1 hour and up 2 hours

- Group C - Flights with a duration above 2 hours and up 3 hours

- Group D - Flights with a duration above 3 hours and up 4 hours

- Group E - Flights with a duration above 4 hours and up 6 hours

- Group F - Flights with a duration above 6 hours and up 10 hours

- Group G - Flights with a duration above 10 hours or more

This categorization reveals that the Brazilian operations have almost $70 \%$ of its services concentrated in flights with duration up to 2 hours. If analyzing 
flights until 3 hours of the period, it returns coverage of more than $90 \%$ of Brazilian flights, as shown in Figure 4.

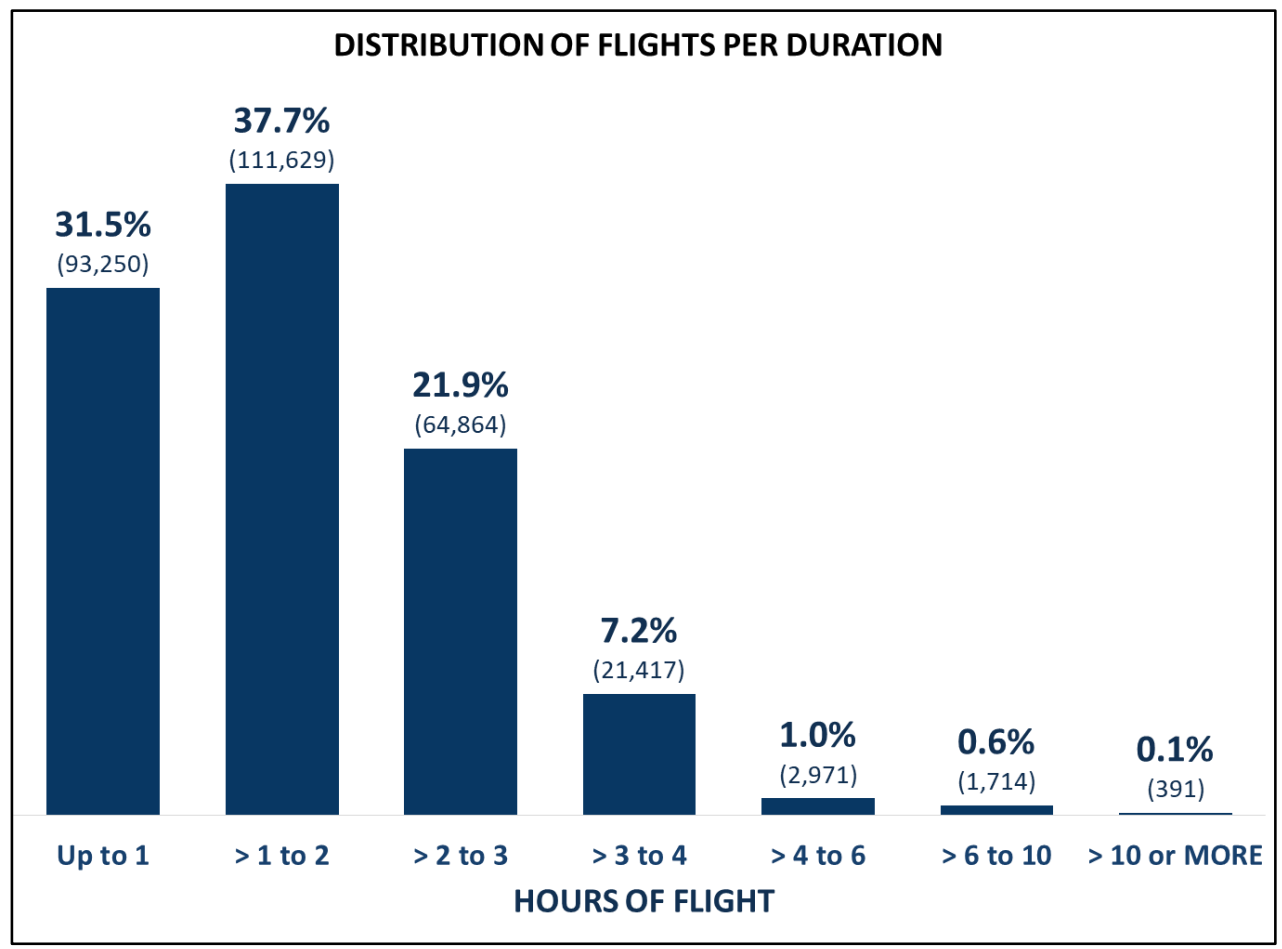

Figure 4. Distribution of flights per duration.

\section{Flight Analysis Outcome}

The historical data of flights provided by the airlines were used to an initial estimation of the "new" Fuel On Board (FOB) using the new proposed rule of 5\% of contingency fuel instead of existing contingency fuel.

For this analysis, the previous existing $10 \%$ quantity was replaced by $5 \%$ to calculate how much fuel each flight would have on landing if it were dispatched using the new percentage contingency fuel.

An intuitive conclusion for reducing the contingency fuel from 10\% to 5\%, is that all flights should have a reduction in the fuel quantity on landing. Since the less fuel the aircraft have in the departure, the less fuel would have in the arrival. However, the current regulation requires $10 \%$ over the flight time, while the new proposal is $5 \%$ over the trip fuel quantity, what turns into a non-linear relation between old and new scenario, invalidating that intuitive relation. Figure 5 shows in yellow the percentage of flights that are "positively" affected by new as it would land with more fuel than before. The blue bars in the same figure represents flights that are affected "negatively" by the change, as it would land with less fuel than before. Both information is clustered by flight time categories. In general, 
approximately $29 \%$ of flights had an increase in their fuel quantity on landing, which confirms the above citation of a non-linear relation between previous and new rule. Very short flights (Category A) are more "positively" affected, while the other categories have more flights "negatively" affected. The most affected flights are concentrated in the Categories B and C. Figure 5 gives details on this analysis.

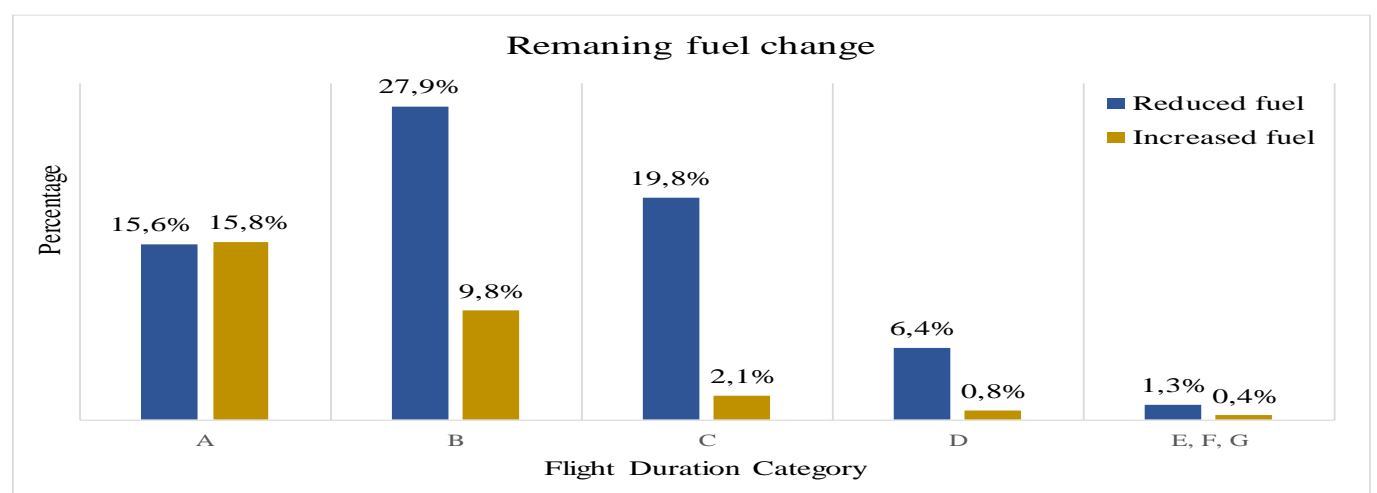

Figure 5. How the Remaining Fuel is Affected by the Change in the Contingency Fuel.

However, even if the change of the current regulation to 5\% is capable of increasing the remaining fuel quantity on the landing of almost $30 \%$ of flights, we still needed to investigate further how the other flights were impacted. The next step was to analyze the flights that had their fuel quantity at landing decreased, and how much remained on board, to find out if any flight might be safely affected by this change. Therefore, the researchers compared the new fuel onboard on landing, applying the 5\% rule, with the final reserve fuel (holding fuel), and observed the difference between them. The objective was to check if there would be any flight with fuel onboard on landing lower than the minimum fuel required by regulation, which could result in an emergency condition. Figure 6 gives the number of observations of flights, grouped by the difference of remaining fuel on landing and final reserve fuel. Negative values identified situations when the flight landed below the minimum fuel required by regulation, while positive values indicate more fuel than the final reserve fuel quantity. 


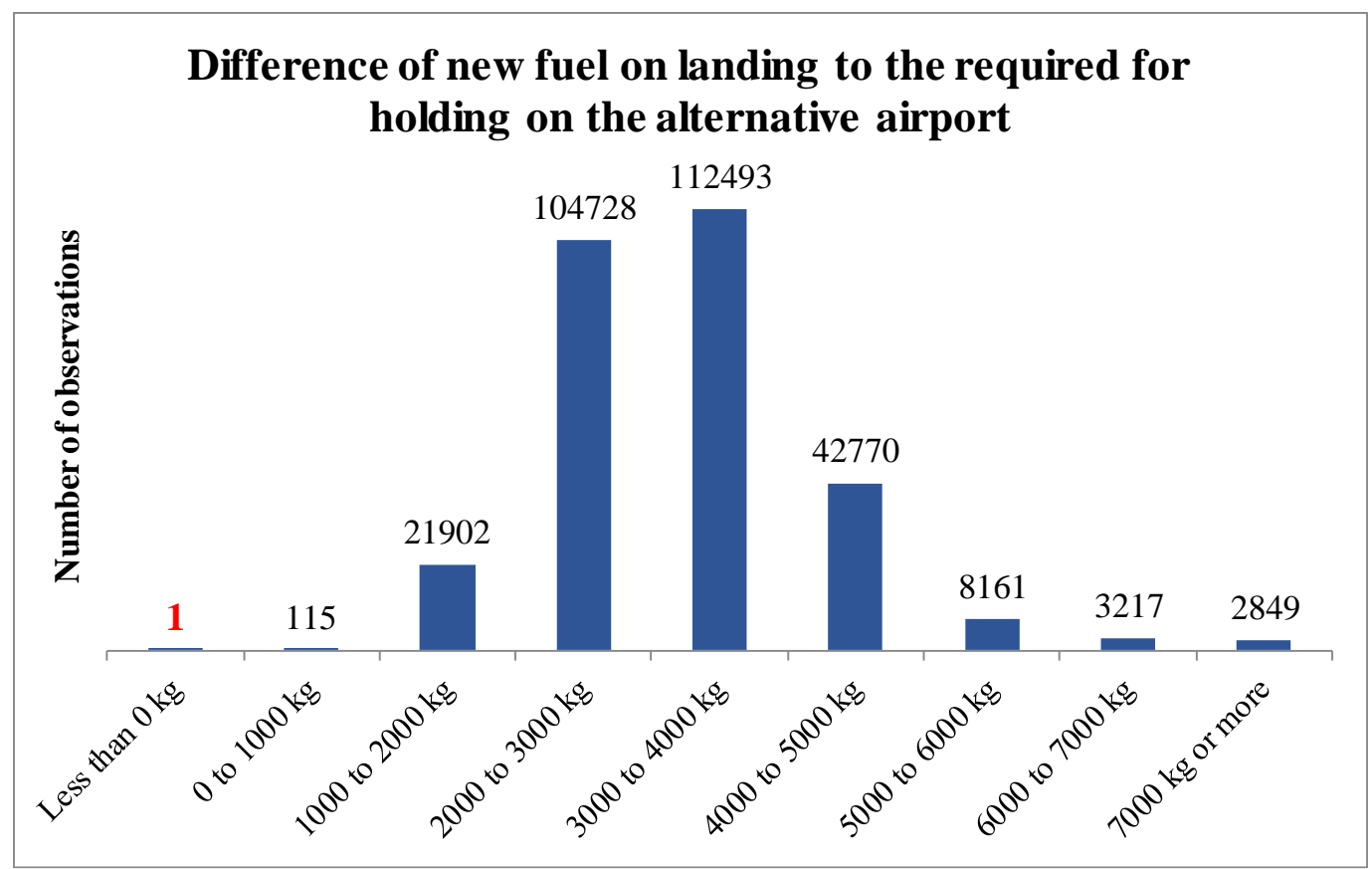

Figure 6. Difference of Fuel on Landing to the Required for Holding on the Alternative Airport.

It is possible to observe that after changing the contingency fuel rule, the majority of flights would land with $2000 \mathrm{~kg}$ up to $4000 \mathrm{~kg}$ more fuel than the minimum reserve. The figure reveals one isolated case in which the aircraft would land with less fuel than the minimum reserve, or in other words, in a fuel emergency condition. Regarding this specific flight, the historical data revealed that even with the current $10 \%$ rule, this flight was in a fuel emergency condition, and for that will not be considered to the purpose of this study.

The Monte Carlo simulation was also divided into separated simulations for each flight category. So the effect of flight consumption differences of short and long flights will not affect the historical data collection. The model created to this simulation requires statistical information, to run random scenarios, from the historical data of the following variables: Taxi Fuel, Planned Trip Fuel, Alternate Fuel, Extra Fuel, Holding Fuel and The relation between Actual and Planned Trip Fuel, also named in this study as Consumption Factor.

The observation of the above variables data determines the type of statistic distribution of the historical representation. This determination is required to define the inputs needed from each variable (mean, mode, standard deviation, etc.) to be inputted in the simulation tool. With the support of the Excel application Oracle Crystal Ball, and using the built-in tool based on Anderson-Darling methodology, 
it was possible to determine the distribution that better adjusted for each dataset. Table 4 presents the results of this analysis.

Table 4

Type of Distributions for Each Historical Observation Dataset

\begin{tabular}{|c|c|c|c|c|c|c|}
\hline & $\begin{array}{l}\text { Taxi } \\
\text { Fuel }\end{array}$ & $\begin{array}{l}\text { Planned } \\
\text { Trip Fuel }\end{array}$ & $\begin{array}{c}\text { Alternate } \\
\text { Fuel }\end{array}$ & $\begin{array}{c}\text { Extra } \\
\text { Fuel }\end{array}$ & $\begin{array}{c}\text { Holding } \\
\text { Fuel }\end{array}$ & $\begin{array}{c}\text { Consumption } \\
\text { Factor } \\
\end{array}$ \\
\hline Group A & $\begin{array}{c}\text { Normal } \\
\text { Distribution }\end{array}$ & $\begin{array}{c}\text { Normal } \\
\text { Distribution }\end{array}$ & $\begin{array}{c}\text { Normal } \\
\text { Distribution }\end{array}$ & $\begin{array}{l}\text { Log-Normal } \\
\text { Distribution }\end{array}$ & $\begin{array}{c}\text { Normal } \\
\text { Distribution }\end{array}$ & $\begin{array}{c}\text { Logistic } \\
\text { Ditribution }\end{array}$ \\
\hline Group B & $\begin{array}{c}\text { Normal } \\
\text { Distribution }\end{array}$ & $\begin{array}{c}\text { Normal } \\
\text { Distribution }\end{array}$ & $\begin{array}{c}\text { Normal } \\
\text { Distribution }\end{array}$ & $\begin{array}{l}\text { Log-Normal } \\
\text { Distribution }\end{array}$ & $\begin{array}{c}\text { T Student } \\
\text { Ditribution }\end{array}$ & $\begin{array}{c}\text { Logistic } \\
\text { Ditribution }\end{array}$ \\
\hline Group C & $\begin{array}{c}\text { Normal } \\
\text { Distribution }\end{array}$ & $\begin{array}{c}\text { Normal } \\
\text { Distribution }\end{array}$ & $\begin{array}{c}\text { Normal } \\
\text { Distribution }\end{array}$ & $\begin{array}{l}\text { Log-Normal } \\
\text { Distribution }\end{array}$ & $\begin{array}{c}\text { Logistic } \\
\text { Ditribution }\end{array}$ & $\begin{array}{c}\text { Logistic } \\
\text { Ditribution }\end{array}$ \\
\hline Group D & $\begin{array}{c}\text { Normal } \\
\text { Distribution }\end{array}$ & $\begin{array}{c}\text { Normal } \\
\text { Distribution }\end{array}$ & $\begin{array}{c}\text { Normal } \\
\text { Distribution }\end{array}$ & $\begin{array}{l}\text { Log-Normal } \\
\text { Distribution }\end{array}$ & $\begin{array}{l}\text { Log-Normal } \\
\text { Distribution }\end{array}$ & $\begin{array}{c}\text { Logistic } \\
\text { Ditribution }\end{array}$ \\
\hline Group E & $\begin{array}{c}\text { Normal } \\
\text { Distribution }\end{array}$ & $\begin{array}{c}\text { Normal } \\
\text { Distribution }\end{array}$ & $\begin{array}{c}\text { Normal } \\
\text { Distribution }\end{array}$ & $\begin{array}{l}\text { Log-Normal } \\
\text { Distribution }\end{array}$ & $\begin{array}{l}\text { Log-Normal } \\
\text { Distribution }\end{array}$ & $\begin{array}{c}\text { Logistic } \\
\text { Ditribution }\end{array}$ \\
\hline Group F & $\begin{array}{c}\text { Normal } \\
\text { Distribution }\end{array}$ & $\begin{array}{c}\text { Normal } \\
\text { Distribution }\end{array}$ & $\begin{array}{c}\text { Normal } \\
\text { Distribution }\end{array}$ & $\begin{array}{l}\text { Log-Normal } \\
\text { Distribution }\end{array}$ & $\begin{array}{c}\text { Logistic } \\
\text { Ditribution }\end{array}$ & $\begin{array}{c}\text { T Student } \\
\text { Ditribution }\end{array}$ \\
\hline Group G & $\begin{array}{c}\text { Normal } \\
\text { Distribution }\end{array}$ & $\begin{array}{c}\text { Normal } \\
\text { Distribution }\end{array}$ & $\begin{array}{c}\text { Normal } \\
\text { Distribution }\end{array}$ & $\begin{array}{l}\text { Log-Normal } \\
\text { Distribution }\end{array}$ & $\begin{array}{c}\text { T Student } \\
\text { Ditribution }\end{array}$ & $\begin{array}{c}\text { T Student } \\
\text { Ditribution }\end{array}$ \\
\hline
\end{tabular}

Then, the researchers calculated the below values to each historical data, based on the required inputs to the simulation model.

The researchers simulated 200,000 flights for each of groups A, B, and C, and 50,000 flights for groups D, E, F, and G, totalizing 800,000 flights simulated to find the remaining fuel. The results are shown in Figures 7 to 13, which provides the frequency of residual fuel values, and reveal the pattern of a Normal distribution for all simulations groups. From each graph, we observe the average value and standard deviation. Following the Empirical Rule, the parameters of mean and standard deviation can be used to define the population covered by the results of a Normal Distribution, where two values of standard deviations result in coverage of $95,4 \%$ of the results (edX,2019).

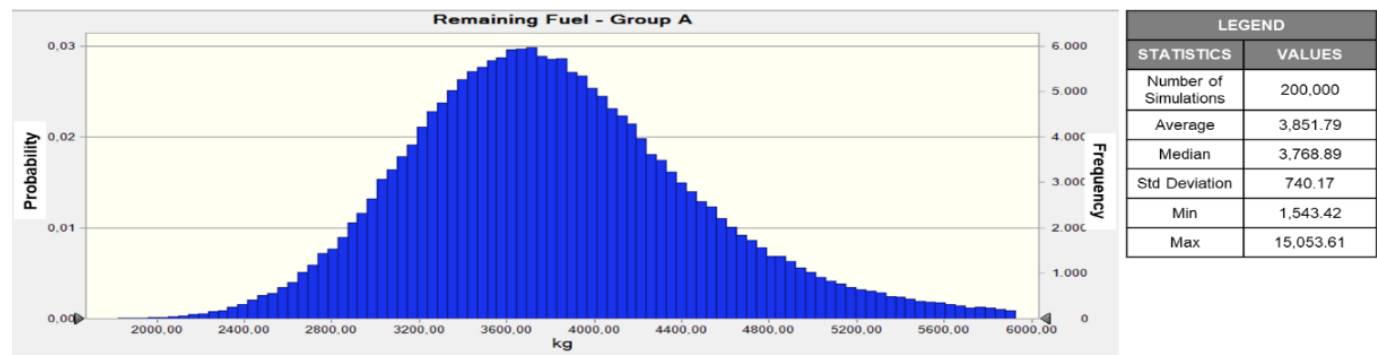

Figure 7. Probability Distribution of Remaining Fuel on Group A Simulation. 


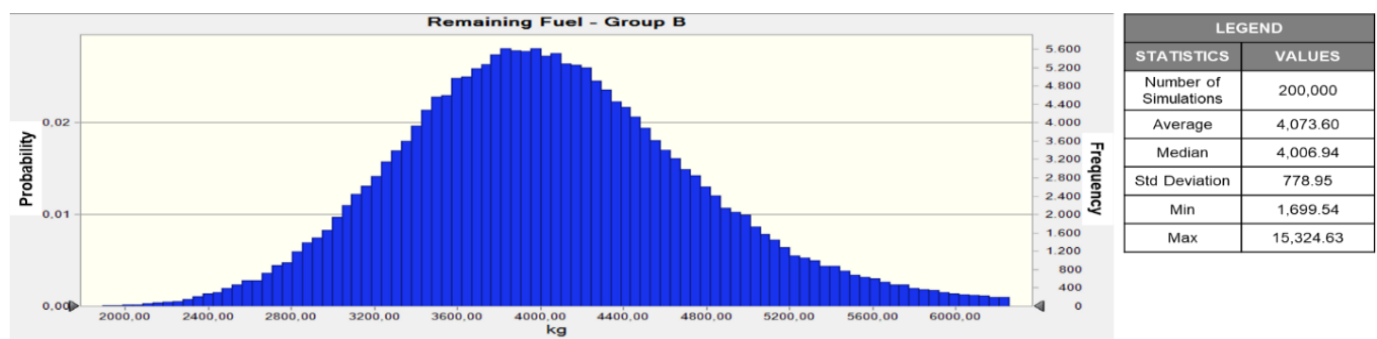

Figure 8. Probability Distribution of Remaining Fuel on Group B Simulation.

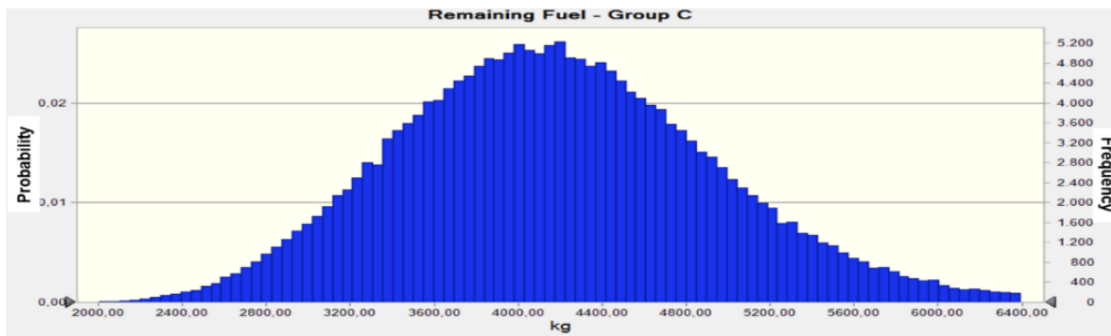

\begin{tabular}{|c|c|}
\hline \multicolumn{2}{|c|}{ LEGEND } \\
\hline STA TISTICS & VALUES \\
\hline $\begin{array}{c}\text { Number of } \\
\text { Simulations }\end{array}$ & 200,000 \\
\hline Average & 4.198 .24 \\
\hline Median & 4.154 .87 \\
\hline Std Deviation & 782.66 \\
\hline Min & 1.895 .42 \\
\hline Max & $11,918.53$ \\
\hline
\end{tabular}

Figure 9. Probability Distribution of Remaining Fuel on Group C Simulation.

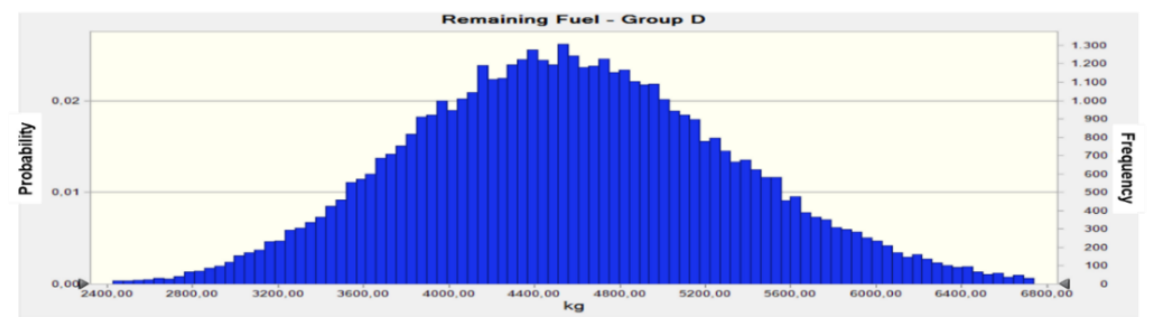

\begin{tabular}{|c|c|}
\hline \multicolumn{2}{|c|}{ LEGEND } \\
\hline STA TISTICS & VALUES \\
\hline $\begin{array}{c}\text { Number of } \\
\text { Simulations }\end{array}$ & 50.000 \\
\hline Average & $4,582.66$ \\
\hline Median & $4,553.74$ \\
\hline Std Deviation & 768.73 \\
\hline Min & $2,138.75$ \\
\hline Max & 10.097 .05 \\
\hline
\end{tabular}

Figure 10. Probability Distribution of Remaining Fuel on Group D Simulation.

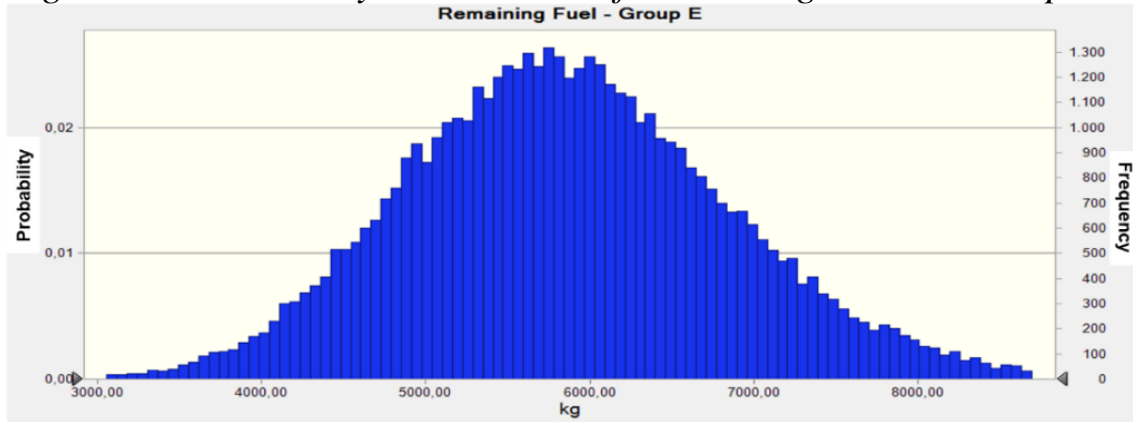

\begin{tabular}{|c|c|}
\hline \multicolumn{2}{|c|}{ LEGEND } \\
\hline STA TISTICS & VALUES \\
\hline $\begin{array}{c}\text { Number of } \\
\text { Simulations }\end{array}$ & 50,000 \\
\hline Average & $5,874.64$ \\
\hline Median & $5,827.10$ \\
\hline Std Deviation & $1,006.40$ \\
\hline Min & $2,323.34$ \\
\hline Max & $11,139.09$ \\
\hline
\end{tabular}

Figure 11. Probability Distribution of Remaining Fuel on Group E Simulation. 


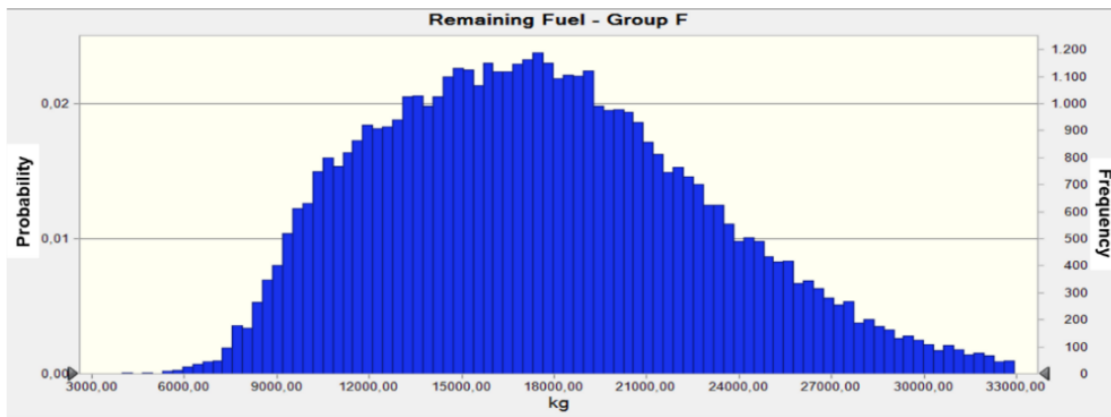

\begin{tabular}{|c|c|}
\hline \multicolumn{2}{|c|}{ LEGEND } \\
\hline STA TISTICS & VALUES \\
\hline $\begin{array}{c}\text { Number of } \\
\text { Simulations }\end{array}$ & 50,000 \\
\hline Average & $17,659.17$ \\
\hline Median & $17,241.63$ \\
\hline Std Deviation & $5,448.34$ \\
\hline Min & $3,335.10$ \\
\hline Max & $48,209.97$ \\
\hline
\end{tabular}

Figure 12. Probability Distribution of Remaining Fuel on Group F Simulation.
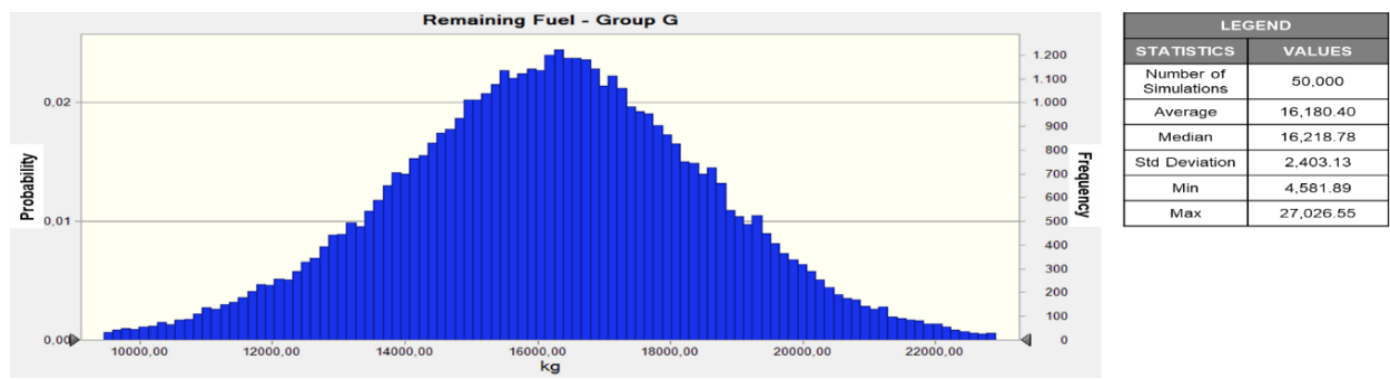

Figure 13. Probability Distribution of Remaining Fuel on Group G Simulation.

Then, applying (adding and subtracting) two values of standard deviations over the average amount of the remaining fuel of each simulation, the researchers built table 5 that confirms that any flight would have the following maximum and minimum remaining fuel, with $95.4 \%$ of probability.

Table 5

Range of Remaining Fuel Value with 95.4\% of Probability

\begin{tabular}{|c|c|c|c|}
\cline { 2 - 4 } & $\begin{array}{c}\text { Average } \\
\text { Remaining Fuel }\end{array}$ & $\begin{array}{c}\text { Minimum } \\
\text { Remaining Fuel }\end{array}$ & $\begin{array}{c}\text { Maximum } \\
\text { Remaining Fuel }\end{array}$ \\
\hline Group A & $3851 \mathrm{~kg}$ & $2371 \mathrm{~kg}$ & $5331 \mathrm{~kg}$ \\
\hline Group B & $2855 \mathrm{~kg}$ & $1297 \mathrm{~kg}$ & $4413 \mathrm{~kg}$ \\
\hline Group C & $2242 \mathrm{~kg}$ & $677 \mathrm{~kg}$ & $3807 \mathrm{~kg}$ \\
\hline Group D & $4582 \mathrm{~kg}$ & $3045 \mathrm{~kg}$ & $6119 \mathrm{~kg}$ \\
\hline Group E & $5874 \mathrm{~kg}$ & $3861 \mathrm{~kg}$ & $7887 \mathrm{~kg}$ \\
\hline Group F & $17659 \mathrm{~kg}$ & $6762 \mathrm{~kg}$ & $28556 \mathrm{~kg}$ \\
\hline Group G & $16180 \mathrm{~kg}$ & $11364 \mathrm{~kg}$ & $20996 \mathrm{~kg}$ \\
\hline
\end{tabular}

Data coming from each simulated flight were also assessed and analyzed separately to compare the remaining fuel and the minimum reserve fuel (holding fuel). The researchers also evaluated if any flight "landed" with less remaining fuel than the minimum required, or in other words, in an emergency condition. Table 6 
presents the resume of simulation results and the comparison between remaining fuel and minimum reserve fuel.

Table 6

Results of Simulations for Remaining Fuel and Difference to Reserve Fuel

\begin{tabular}{c|c|c|c}
\cline { 2 - 4 } & Flights simulated & $\begin{array}{c}\text { Smallest Remaining } \\
\text { Fuel }\end{array}$ & $\begin{array}{c}\text { Smallest difference } \\
\text { to the reserve fuel }\end{array}$ \\
\hline Group A & 200,000 & $1543 \mathrm{~kg}$ & $+559.90 \mathrm{~kg}$ \\
\hline Group B & $\mathcal{I} 200,000$ & $1699 \mathrm{~kg}$ & $+676.52 \mathrm{~kg}$ \\
\hline Group C & 200,000 & $1895 \mathrm{~kg}$ & $+847.64 \mathrm{~kg}$ \\
\hline Group D & 50,000 & $2138 \mathrm{~kg}$ & $+996.39 \mathrm{~kg}$ \\
\hline Group E & 50,000 & $2323 \mathrm{~kg}$ & $+731.63 \mathrm{~kg}$ \\
\hline Group F & 50,000 & $3335 \mathrm{~kg}$ & $+280.16 \mathrm{~kg}$ \\
\hline Group G & 50,000 & $4581 \mathrm{~kg}$ & $+47.18 \mathrm{~kg}$ \\
\hline
\end{tabular}

Our study shows in the last column of Table 6 that after 800.000 simulations using historical data. No flight would land below minimum reserve fuel (holding fuel) after contingency fuel was changed to $5 \%$ of the Trip Fuel.

\section{Conclusions and Recommendations}

The researchers divided this study into two separates analyses. The first one looked at a group of over two hundred and ninety thousand flights from two of the largest Brazilian Airlines. The researchers used planning data and also real flight data to be able to understand further if the proposed change in the fuel calculation method, would impact the remaining fuel amount after landing. By doing that, we were able to evaluate if there will be a decrease in Flight Safety if the regulation change is approved. The result showed, with a confidence interval of $99.92 \%$, that $71 \%$ of flights had the fuel on landing reduced when compared with the current regulation. And surprisingly, the remaining $29 \%$ of flights had an increase in their fuel quantity on landing. However, the information we were looking for is to find out if any flight has arrived on the ground after landing with a fuel amount less them the regulatory minimum, which would put it into a fuel emergency condition. The final result was that only one flight amongst over almost three hundred thousand has landed in a fuel emergency condition. However, the researchers decided not to consider this information to be valid since it has arrived in an emergency fuel condition even under the actual fuel regulatory rules, meaning also having the $10 \%$ fuel contingency fuel available.

The second part of the study was to randomly simulate thousands of flights, using the Monte Carlo simulation, to see if it would point to similar results of the first study. After using random entries within 800,000 fuel consumption values, the 
simulation statistically demonstrated that no flight entered the fuel emergency condition, reinforcing the same conclusion achieved in the first study.

By having both studies getting the same end, we are now able to scientifically support that the change in the Brazilian fuel regulation can be made without decreasing our Flight Safety. All results were sent to ABEAR to be presented to ANAC together with the fuel data from all significant Brazilian airlines. All these documents were given to ANAC to technically support the regulatory change that could lead to a US\$ $6.5 \mathrm{M}$ per year in fuel savings for Brazilian Aviation, considering $0,21 \%$ of the current fuel budget of the three biggest airlines flying in Brazil.

\section{Limitations of the Study}

The first limitation was the availability of flight data fuel records. The researchers were only able to get data from two of the three major Brazilian Airlines. Although it was sufficiently representative and it would be better if this research had been supplied with the material from the third airline. Another significant limitation was the availability of free software to develop the simulations. Although the researchers have positive and reliable results using the Monte Carlo simulation application and believe that would enrichen the study to have used aviation-related software such as Amadeus, Sabre, or Jeppesen. Other studies related to impacts in-flight operations use to also analyze data by applying seasonality effects. This research did not have additional data (more than one year) to evaluate the effect of the seasonality on fuel planning and consumption. However, the researchers understand that the evaluation of every single flight separately was sufficient to achieve the research objective.

\section{Study Implications}

The researchers believe our review is the only one available on this matter that have used simulation and also that took into account the statistical value of the data studied. The Airlines only gave ABEAR a mathematical study, not guaranteeing a specific significance interval. The quality and significance of our data should help convince those who have doubts about the maintenance of the Flight Safety values.

This study supports that all countries that have already made this change in fuel calculation policies were right when they took this decision and that Brazilian Authorities should head in the same way. This study also can solve any doubts the reader should have of the feasibility of this change regarding fuel management safety. ABEAR proposed this change, and it is currently under the ANAC evaluation process. The proposal was approved in February 2020 and became the new law starting April $1^{\text {st }}, 2020$. 


\section{References}

AAC. (2019) - Autoridade de la Aviacion Civil Colombia. RAC 121 -Requisitos de Operación Operaciones Domésticas e Internacionales Regulares y no Regulares. Retrieved from: http://www.aerocivil.gov.co/normatividad/ RAC/ RAC\%20\%20121\%20-\%20Requisitos\%20\%20de\%20Operaci\% C3\%B3n\%20-\%20Operaciones\%20Dom\%C3\%A9sticas\% 20e\%20Internales-Regulares\%20y\%20no\%20Regulares.pdf

AACP. (2019) - Autoridad Aeronáutica Civil Panamá - Libro X-Parte II Reglas De Vuelo Y Operación General - Aviones Grandes $Y$ Turborreactores. Retrieved from http://sigob.aeronautica.gob.pa/snra/ subtipo/2/ficha/663/archivo/2520/pdf

Airbus. (2004). Getting to grips with fuel economy. Issue 4 - October 2004.

Altus, S. (2009). Effective flight plans can help airlines economize. Aero Quarterly - Boeing Company. Retrieved from https://www.boeing.com/ commercial/aeromagazine/articles/qtr_03_09/article_08_1.html

ABEAR. (2018) - Associação Brasileira das Empresas Aéreas - Panorama Abear dados e estatísticas. Retrieved from: http://panorama.abear.com.br/dadose-estatisticas/custos-das-empresas/

ANAC. (2018) - Agencia Nacional de Aviação Civil - Regulamento Brasileiro da Aviação Civil 121, Emenda 05. Retrieved from https://www.anac.gov.br/ assuntos/ legislacao/legislacao-1/rbha-e-rbac/rbac/rbac-121

Andreeva-Mori, A., \& Uemura, T. (2018). Efficiency analysis of speed managed descent in the presence of wind prediction error. Retrieved from https://www.jstage.jst.go.jp/article/tjsass/61/1/61_T-16-48/_pdf

Boeing. (2010). Flight planning and performance manual - 737 800WSFP2, Boeing Document D6etA008-ZZ019, Revision 3.

CASA. (2018) - CASA 29/18 - Civil aviation (fuel requirements) instrument 2018. Retrieved from https://www.legislation.gov.au/Details/F2018L00644 /Html/Text\#_Toc514142495

CCAR. (2005). CCAR 121.661 Operation certification rules for civil aviation transportation carriers with large airplanes. Retrieved from http://conmachine.com/pluginfile.php/1901/mod_resource/content/1/CCA R-121.pdf

DGAC Chile. (2017). Direccion General de Aeronautica Civil Chile. DAN121 Edición 2 - Requisitos de Operación: Operciones Nacionales, Internacionales, Regulares y No Regulares. Retrieved from https://www.dgac.gob.cl/transparencia/pdf2017/DAN_121_Ed.2_Enm.8.p df

DGAC Peru. (2018). Direccion General de Aeronautica Civil Peru. RAP 121 Requisitos de Operación - Capítulo P - Retrieved from 
http://portal.mtc.gob.pe/transportes/aeronautica_civil/normas/documentos/ rap/2018/RAP_121/17\%20RAP\%20121_Capitulo_P_enm_1.pdf

Denuwelaere, S. (2012). A new approach to cost of weight. eJournal Aircraft It. Retrieved from: https://www.aircraftit.com/articles/a-new-approach-tocost-of-weight-cow/?area=ops

Dispatcher.org (2019). Library - dispatch profession - job description. Retrieved from: https://www.dispatcher.org/dispatcher/job-description

EASA. (2019). European Union aviation safety agency - air operations. Retrieved from https://www.easa.europa.eu/sites/default/files/dfu/ EasyAccessRules_for_AirOperations-Oct2019.pdf

EASA. (2012). European Union aviation safety agency - regulations commission regulation (EU) No 965/2012. Retrieved from https://eurlex.europa.eu/LexUriServ/LexUriServ.do?uri=OJ:L:2012:296:0001:0148: EN:PDF

Edx.org. (2019). Chapter 4. Normal distributions. Retrieved from: https://prodedxapp.edx-cdn.org

FAA. (2015). Federal Aviation Administration - FSIMS - Flight standards information management system - volume 3, chapter 25 - Retrieved from http://fsims.faa.gov/PICResults.aspx?mode=EBookContents\&restricttocat egory $=$ all $\sim$ menu

FAA. (2019). - Federal Aviation Administration - part 121 - operating requirements: Domestic, flag, and supplemental operations. Retrieved from https://www.ecfr.gov/cgi-bin/text-idx?c=ecfr\&tpl=/ecfrbrowse Title14/14tab_02.tpl

Fachhochschule, Z. (2017). Fuel economy as function of weight and distance. Retrieved from https://digitalcollection.zhaw.ch/bitstream/11475/1896/ 2/Steinegger_Fuel_Economy_for_Aircraft_Operation_as_a_Function_of_ Weight_and_Distance_v1-0.pdf

Flight Safety Foundation. (2018). Fuel - flight planning definitions. Retrieved from https://skybrary.aero/index.php/Fuel_-_Flight_Planning_Definitions

Flouris, T. G., \& Yilmaz, A. K. (2011). Risk management and corporate sustainability in aviation. Retrieved from https://ebookcentral.proquest.com

Hao, L., Hansen, M., \& Ryerson, M. S. (2016). Fueling for contingencies: The hidden cost of unpredictability in the air transportation system. Transportation Research Part D, 44, 199-210. doi:10.1016/j.trd.2016.02.016

ICAO. (2013). Safety management manual (3rd ed.). Retrieved from https://www.icao.int/safety/SafetyManagement/Documents/Doc.9859.3rd $\% 20$ Edition.alltext.en.pdf 
ICAO. (2018). Annex 6 - Operation of Aircraft Part I - International Commercial Air Transport - Aeroplanes (11 ${ }^{\text {th }}$ ed.).

Johnson, M. E., \& Gonzalez, A. (2013). Estimating cost savings for aviation fuel and $\mathrm{CO} 2$ emission reductions strategies. Collegiate Aviation Review International, 32(1), 79-102. doi:10.22488/okstate.18.100513

Popov, G., Lyon, B. K., \& Hollcroft, B. (2016). Risk assessment: A practical guide to assessing operational risks. Retrieved from https://ebookcentral.proquest.com

Ryan, J., \& Heavey, C. (2006). Process modeling for simulation. Computers in Industry, 57(5).

Schneider, D. C., Jr. (2009). An exploratory analysis of commercial airline contingency fuel calculations: With forecasting and optimization. Retrieved from scholarspace.library.gwu.edu > downloads

Shreĭder, I. A., \& Buslenko, N. P. (1966). The monte carlo method: The method of statistical trials. New York; Oxford: Pergamon Press.

Transport Canada (2019). TP14371E - AIM - aeronautical information manual. Retrieved from https://www.tc.gc.ca/documents/AIM_2019-

1_E_ACCESS.pdf 